\section{DIGITAL COMMONS \\ @ UNIVERSITY OF SOUTH FLORIDA}

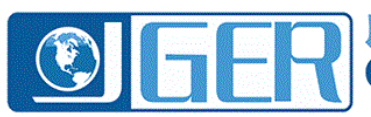

Journal of

Global Education and Research

June 2019

\title{
Self-regulated learning strategies of adult learners regarding non- native status, gender, and study majors
}

Xi Lin

East Carolina University, linxi18@ecu.edu

Follow this and additional works at: https://digitalcommons.usf.edu/jger

Part of the Adult and Continuing Education Commons, and the Educational Psychology Commons This Refereed Article is brought to you for free and open access by the M3 Center at the University of South Florida Sarasota-Manatee at Digital Commons @ University of South Florida. It has been accepted for inclusion in Journal of Global Education and Research by an authorized editor of Digital Commons @ University of South Florida. For more information, please contact digitalcommons@usf.edu.

\section{Recommended Citation}

Lin, X. (2019). Self-regulated learning strategies of adult learners regarding non-native status, gender, and study majors. Journal of Global Education and Research, 3(1), 58-70. https://www.doi.org/10.5038/

2577-509X.3.1.1018

Corresponding Author

Xi Lin, 209 Ragsdale Hall, East Carolina University, Greenville, 27858, NC, USA

Revisions

Submission date: Aug. 7, 2018; 1st Revision: Oct. 21, 2018; 2nd Revision: Jun. 16, 2019; Acceptance: Jun. 25, 2019 


\title{
Self-Regulated Learning Strategies of Adult Learners Regarding Non-Native Status, Gender, and Study Majors
}

\author{
$\mathrm{Xi}$ Lin \\ College of Education Faculty \\ East Carolina University, United States \\ linxi18@ecu.edu
}

\begin{abstract}
The number of adult learners is growing rapidly in the US institutions, and these learners have become an important student population in colleges. Therefore, it is important to understand their learning strategies in order to better assist them to achieve academic goals. Meanwhile, US institutions have dramatically increased the number of international English as a Second Language (ESL) students. Thus, to better understand these students' learning strategies and help them succeed is a need. Therefore, the purpose of this study is to investigate the differences in learning strategies (i.e., cognitive and metacognitive strategies and resource management strategies) of adult learners regarding non-native status (international ESL learner vs. native speaker American learner), gender, and study majors. Two hundred and thirty-six adult learners participated in the study, and results indicated all these three variables have significant influences on these learners' learning strategies.
\end{abstract}

Keywords: international ESL, cognitive and metacognitive strategies, resource management strategies

\section{Introduction}

Learners do not simply receive information from instructors, but also process information using mental activities (Hosenfeld, 1976; Yang, Hwang, \& Yang, 2013). Among the growing student populations, adult learners are typically identified as 25 years old or over and do not continue enrolling as students in a formal education system after completing their first or former education (Bye, Pushkar, \& Conway, 2007; Markle, 2015). In addition, they are often considered as selfregulated learners, who usually engage in self-generated thoughts, actions, and feelings when pursing academic goals (Bandura, 1997; Kellenberg, Schmidt, \& Werner, 2017; Zimmerman, 2000). These learners consider education as "a process of developing increased competence to achieve their full potential in life" (Knowles, 1980, p. 44), and they desire to "be able to apply whatever knowledge and skill they gain today to living more effectively tomorrow" (Knowles, 1980, p. 44). Meanwhile, traditional students who continue enrolling as students in a formal education system are less self-regulated (Spitzer, 2000). Compared to traditional students, adult learners are more goal-oriented, and their primary reasons for returning to school are to seek better career opportunities and/or simply enjoy learning (Lin \& Wang, 2015). Therefore, their unique goals of returning for learning would influence their self-regulated learning strategies.

Besides adult learners, international students are another student population which is increasing rapidly in US institutions (Cantwell, 2015). For example, more than one million international 
students studied in universities in the US in year 2017 to 2018, and the majority of those international students originally come from non-English speaking countries such as China, South Korea, and Saudi Arabia (Opendoors, 2018). The adjustment to academic and social life in the US institutions of this student population has been investigated for years (Hirai, Frazier, \& Syed, 2015; Mesidor \& Sly, 2016; Lin \& Wang, 2015; Yakunina, Weigold, \& Weigold, 2013), while limited studies have examined international English as a Second Language (ESL) adult learners, their selfregulated learning strategies during the learning process, or comparison of their self-regulated learning strategies with those of native speaker American adult learners. Furthermore, there is no study examining self-regulated learning strategies of adult learners in different majors.

As a result, the purpose of this study was to investigate the differences in learning strategies (i.e., cognitive and metacognitive strategies and resource management strategies) of adult learners regarding non-native status (international ESL learner vs. native speaker American learner), gender, and study majors. It is expected, through this study, educational professionals would have a better understanding of diverse adult learners and help them achieve academic success based on various learning strategies.

\section{Literature Review}

\section{Self-Regulated Learning}

Zimmerman (2008) defined self-regulated learning as "the self-directive processes and self-beliefs which enable learners to transform their mental abilities, such as verbal aptitude, into an academic performance skill, such as writing" (p. 166). According to his theory, students often use selfregulated learning to acquire academic skills, such as "setting goals, selecting and deploying strategies, and self-monitoring one's effectiveness" (Zimmerman, 2008, p. 166). In short, selfregulated learning strategies involve: (a) setting specific goals, (b) utilizing task strategies, (c) displaying high levels of self-efficacy and intrinsic interest, and (d) self-monitoring and selfreflecting on performance outcomes (Zimmerman \& Schunk, 2008). Pintrich and Garcia (1991) described self-regulated learning as continuous adjustment of individuals' cognitive activities and processes to the requirement of a certain learning situation.

Based on the definitions of self-regulated learning, self-regulated learners are defined as active learners who manage their own learning experiences efficiently through different methods (Schunk \& Zimmerman, 1994). These learners have also been considered as autonomous, reflective, and efficient learners who have the will and motivation to understand, direct, and control their own learning (Littlejohn, Hood, Milligan, \& Mustain, 2016; Pintrich, 1999; Schunk \& Zimmerman, 1994). Studies noted self-regulated learners have adaptive learning goals which encourage them to make efforts in order to reach these goals and they modify their strategies in response to shifting task demands (Littlejohn et al., 2016; Pintrich \& Garcia, 1991; Zimmerman, 1989). Furthermore, self-regulated learners are motivated, independent, and metacognitive during the learning process and they often obtain high academic achievements (Broadbent \& Poon, 2015; Mega, Ronconi, \& De Beni, 2014; Zimmerman, 1990; Zimmerman \& Martinez-Pons, 1986). Additionally, these learners often actively manage their learning environment as well as control useful resources during the learning process (Wolters, 1998; Pintrich, 1999).

\section{Self-Regulated Learning Conceptual Framework}

Studies identified several self-regulated learning strategies, such as self-evaluating, organizing and transforming, seeking information, goal-setting and planning, and rehearsing (Zimmerman \& 
Lin: Self-regulated learning strategies of adult learners regarding non-native status, gender, and study majors

Martinez-Pons, 1986). Researchers (Pintrich \& Garcia,1991; Pintrich, Smith, Garcia, \& McKeachie, 1993) later developed a self-regulated learning conceptual framework to evaluate students' motivational orientations and their use of various learning strategies for college courses. This model specifically assesses students' use of cognitive and metacognitive strategies and their management of various resources during the learning process.

\section{Cognitive and Metacognitive Self-Regulatory Strategies}

Cognitive and Metacognitive self-regulatory strategies refer to how learners manipulate information in response to task demand and functions designed in order to assess and control the use of cognitive strategies (Pintrich \& Garcia, 1991). Cognitive strategies are usually applied to both simple memory work and more complex work. Specifically, cognitive strategies are comprised of rehearsal, elaboration, and organization. According to Pintrich (1999), rehearsal strategies "involve the recitation of items to be learned or the saying of words aloud as one reads a piece of text" (Pintrich, 1999, p. 460), and these strategies help learners "select important information from lists or texts and keep this information active in working memory, albeit they may not reflect a very deep level of processing" (Pintrich, 1999, p. 460). Elaboration strategies refer to paraphrase or summarize the materials to be learned, as well as reorganize and connect ideas from the note (Mousoulides \& Philippou, 2005). Organization strategies include behaviors such as "selecting the main idea from text, outlining the text or material to be learned, and using a variety of specific techniques for selecting and organizing the idea in the material" (Pintrich, 1999, p. 460). Those strategies would foster active cognitive engagement in learning which then leads to high academic achievement (Broadbent \& Poon, 2015; Wolters \& Hussain, 2015).

Furthermore, studies indicated metacognitive and self-regulated strategies have a major influence on students' achievements (Kitsantas, Steen, \& Huie, 2017), and these strategies include learners' planning, monitoring, and regulating activities (Yukselturk \& Bulut, 2007; Zimmerman \& Martinez-Pons, 1986, 1988). Learners would use metacognition in solving complex problems and thinking about and critique their own cognitions (Flavell, 1978). For example, students who adopt these types of strategies usually plan their use of cognitive strategies, monitor their thinking and behavior, and finally apply regulating activities to modify their study behaviors during the learning process.

\section{Resource Management Strategies}

Resource management strategies represent learners' abilities to establish conditions which may facilitate their learning (Pintrich \& Garcia, 1991). These strategies are comprised of time and study environment (TE), effort regulation (effort), peer learning (peer), and help seeking (help). TE refers to how learners manage their study time and learning environment. Effort represents the degree of their commitment to achieving their study goals. Peer indicates how often learners are willing to study with their peers, and help indicates how often they are willing to ask their classmates or instructors for help.

\section{Gender Differences in Self-Regulated Learning}

Gender has been examined as a significant factor in using self-regulated learning strategies. Studies indicated female learners are more active strategy users than male learners (Garrison \& Akyol, 2015). For example, Zimmerman and Martinez-Pons (1990) investigated self-regulated learning strategies among fifth, eighth, and eleventh graders. They found girls tend to use metacognitive self-regulated strategies to manage their study environment more often than boys. 
Garrison and Akyol (2015) also discovered female eighth graders have a higher level of metacognitive skills such as perception of performance, the use of prior knowledge, and the use of various learning strategies and monitoring the learning process compared to male eighth graders. Similarly, Pokay and Blumenfeld (1990) found high school female students use more metacognitive, cognitive, and resource management strategies compared to their male counterparts. Bidjerano (2005) examined the extent to which self-regulated learning strategies vary among male and female undergraduate students. Results indicated female students tend to use rehearsal, elaboration, organization, metacognition, time management, and effort more often than male students. However, no gender difference was found with peer studying and help seeking strategies among those participants. Other researchers discovered female college students do better in memorizing and have a higher level of self-regulation than their male counterparts (Chen \& Lin, 2018). Some studies, however, argued male college students more often used self-regulated learning strategies compared to female college students (Baily, 1996), while others found no significant or very few differences between men and women college learners (Shmais, 2003; Szoke \& Sheorey, 2002).

\section{Study Major Differences in Self-Regulated Learning}

Self-regulation has been found to be an important strategy for science, technology, engineering, and mathematics (STEM) learning as it is highly desirable for STEM college students to apply and synthesize the fundamental disciplinary concepts (Miller, 2015). Chen and Lin (2018) investigated approximately one million college students in Taiwan and discovered students who major in STEM-related domains (e.g., science, engineering) expressed a lower level of self-related regulation compared to students in non-STEM related areas. More research effort is needed to examine the self-regulated learning of students in both STEM and non-STEM academic disciplines in order to promote their self-regulation and learning outcome.

\section{Self-Regulated Learning Strategies of International ESL Learners}

The ESL learners are typically identified as individuals who learn English in countries where English is used as a tool for communication (Iwai, 2011; Ozturk, 2015). As the number of international ESL students increases, researchers have been investigating these learners' learning strategies in order to help them enhance their academic performance. Early studies revealed that metacognitive strategies are most frequently used by international ESL students, while rehearsal strategies are least used (Goh \& Foong, 1997). Similarly, Poole (2005) found international ESL students of both genders use cognitive and metacognitive strategies with a medium or high frequency. However, most of those studies focused on international ESL students' self-regulated learning strategies in English learning courses (Hong-Nam \& Leavell, 2006; Iwai, 2011; Kim, Wang, Ahn, \& Bong, 2015), no study investigated these learners' self-regulated learning strategies when they are taking their major courses.

\section{Self-Regulated Learning Strategies of Adult Learners}

Compared to traditional learners, who are typically aged 18-22 years old or younger with continuous enrollment as students, adult learners are usually identified as 25 years of age and older, and they do not continuously enroll as students in a formal education system (Bye at al., 2007; Kasworm, Polson, \& Fishback, 2002). These learners have become an important student group and they are identified as motivational and goal-oriented learners (Lin \& Wang, 2015; Rabourn, Shoup, \& BrckaLorenz, 2015). Additionally, adult learners often apply metacognitive skills to understand course materials, and they usually use a range of metacognitive skills to approach 
Lin: Self-regulated learning strategies of adult learners regarding non-native status, gender, and study majors

learning and balance the demands of their time (Mokhtar, Rawian, Yahaya, Abdullah, \& Mohamed, 2017). Among previous studies, no research has explored resource management strategies of these learners, as well as the difference of self-regulated learning strategies regarding their non-native status, gender, and study majors. Therefore, the purpose of this study is to investigate the differences in learning strategies of adult learners regarding non-native status, gender and study majors,

- Research Question 1: What are the differences between cognitive and metacognitive strategies (CMS) of adult learners regarding non-native status, gender, and study major?

- Research Question 2: What are the differences between resource management strategies (RMS) of adult learners regarding non-native status, gender, and study major?

\section{Methods}

\section{Participants}

Data were collected from a large southeastern research institution in the US. The sample of this study was graduate students for the reason that the majority of graduate programs were adult learners, and they seek to enhance competition in the workplace and advance professional careers (Hegarty, 2011). Only adult learners were selected as the participates of this study. The age and academic path were used as the criteria to identify these learners. Students who were 25 years old or over and did not continue to enroll in a formal education system after completing their first or former education were classified as adult learners (Bye et al., 2007), others were excluded from the study.

A total number of 240 adult learners participated in this research with 236 usable respondents (usable rate equals to 98\%). Among the participants, $99(41.9 \%)$ were male students and 136 $(57.5 \%)$ were female students. Most of the participants identified themselves as White or Caucasian (70.8\%), followed by Asian or Pacific Islander (16.9\%), Hispanic or Latino (4.7\%), African American (4.2\%), and others (3.4\%). This study divided study majors into STEM (science, technology, engineering, and math) and non-STEM as the academic success for STEM and nonSTEM students has become an important topic (Han, Capraro, \& Capraro, 2015; Whalen \& Shelley, 2010). Ninety-nine (41.9\%) of the participants majored in STEM fields such as Electronic Engineering, Math and Statistics, while 137 (58.1\%) of the students were in non-STEM fields such as Communication or Finance. In terms of non-native status (international ESL learner vs. native speaker learner from the US), 55 (23.3\%) were international ESL learners and 179 (75.8\%) were native speaker American students. A goodness of fit test indicated that the sample can accurately represent the student population of this university $\left(\chi^{2}=.04, p=.84\right)$.

\section{Instrument}

The Motivated Strategies for Learning Questionnaire (MSLQ) along with a demographic questionnaire were used in the study. MSLQ, which consisted of 81 items, was developed by Pintrich and Garcia (1991). Students rated themselves on a 7-point Likert scale, from 1 (not at all true of me) to 7 (very true of me). Scores for the individual scales were computed by taking the mean of the items which made up the scale. The Cronbach's alpha of MSLQ ranges from 0.52 to 0.93 .

The MSLQ instrument, which consists of 15 sections, is modular, and it allows scholars to use sections together or individually. Therefore, based on previous literature and the research questions 
of the study, eight sections of MSLQ were used including rehearsal (e.g., I memorize key words to remind me of important concepts in this class), elaboration (e.g., I try to apply ideas from course readings in other class activities such as lecture and discussion), organization (e.g., I make simple charts, diagrams, or tables to help me organize course materials), metacognitive self-regulation (e.g., I ask myself questions to make sure I understand the material I have been studying in this class), time and study environment (TE) (e.g., I make sure I keep up with the weekly readings and assignments for this course), effort regulation (effort) (e.g., I work hard to do well in the class even if I don't like what we are doing), peer learning (peer) (e.g., I try to work with other students from this class to complete the course assignments), and help seeking (help) (e.g., I ask the instructor to clarify concepts I don't understand well). The original Cronbach's alpha of the sections which were used in this study ranges from 0.52 to 0.79 , while the Cronbach's alpha for these sections in the present study ranges from 0.70 to 0.72 . Therefore, all sections are considered reliable in this study as Cronbach's alpha above 0.70 is considered acceptable (Cortina, 1993).

\section{Procedures}

An electronic anonymous questionnaire was hosted in the Qualtrics platform, and the information letter which was approved by IRB was displayed in the first page of the survey. Once participants clicked Agree and Continue, they were requested to think about a course they recently took in their study majors and rate the learning strategies they used for this course. Invitation emails with the link to the online survey were sent through the Graduate School, the Multicultural Center, and several student organizations to students who enrolled in this southeastern research institution. Two reminders were sent after the initial invitation, with a total of three emails during the spring semester of 2016. Participants were also instructed to ignore the survey reminders if they already completed it.

\section{Data Analysis}

Data were analyzed through the SPSS version 23. Outliers were deleted by examining Mahalanobis Distance. Factorial MANOVA was used to explore the two research questions. The $p$ value of Box's M was set as 0.001 (Mertler, \& Vannatta, 2002), and the alpha level was set at $p$ equals 0.05 .

\section{Findings}

\section{RQ1: What are the differences between resource management strategies (RMS) of adult learners regarding non-native status, gender, and study major?}

Box's $M$ test indicated covariance matrices of the dependent variables were equal across groups $(p=0.1)$. According to Wilks' Lambda statistic, student status had a statistically significant influence on the cognitive and metacognitive strategies $(F=4.14, p=0.003)$. See Table 1 .

According to univariate ANOVA results, rehearsal $\left(F_{(1,233)}=4.2, p=0.042\right.$, partial eta squared $\left.\left(\eta^{2}\right)=0.02\right)$ and organization $\left(F_{(1,233)}=14.4, p<0.001\right.$, partial $\left.\eta^{2}=0.06\right)$ are significantly different based on the distinct students' status with a small or moderate effect size, respectively. To be specific, international ESL adult learners more often apply rehearsal $(M=5.2, S D=1.1)$ and organization $(M=5.8, S D=0.9)$ strategies than American adult learners. 
Table 1. Non-Native Status Main Effect of Cognitive and Metacognitive Strategies (CMS)

\begin{tabular}{|c|c|c|c|c|c|c|c|}
\hline \multirow[t]{2}{*}{ CMS } & \multicolumn{2}{|c|}{$\begin{array}{c}\text { American } \\
\text { Learners } \\
(n=179)\end{array}$} & \multicolumn{2}{|c|}{$\begin{array}{c}\text { International ESL } \\
\text { learners } \\
(n=54)\end{array}$} & \multirow[t]{2}{*}{$F$} & \multirow[t]{2}{*}{$p$} & \multirow[t]{2}{*}{ Partial $\eta^{2}$} \\
\hline & $M$ & $S D$ & $M$ & $S D$ & & & \\
\hline Rehearsal & 4.8 & 1.3 & 5.2 & 1.1 & 4.1 & 0.042 & 0.02 \\
\hline Organization & 5 & 1.3 & 5.8 & 0.9 & 14 & $<0.001$ & 0.06 \\
\hline
\end{tabular}

Note. $N=236$, Significance level $=.05$

RQ2: What are the differences between resource management strategies (RMS) of adult learners regarding non-native status, gender, and study major.

Box's M test indicated covariance matrices of the dependent variables are equal across groups ( $p$ $=0.4)$. According to Wilks' Lambda statistic, students' status has a statistically significant influence on their resource management strategies $(F=9, p<0.001)$. See Table 2 .

According to univariate ANOVA results, effort $\left(F_{(1,233)}=9.2, p=0.03\right.$, partial $\left.\eta^{2}=0.04\right)$, peer $\left(F_{(1,233)}=16, p<0.001\right.$, partial $\left.\eta^{2}=0.07\right)$, and help $\left(F_{(1,233)}=23, p<0.001\right.$, partial $\left.\eta^{2}=0.09\right)$ are significantly different based on the diverse students' status with a small or moderate effect size, respectively. To be specific, international ESL adult learners more often study with their peers $(M$ $=4.5, S D=1.5)$ and seek help from their classmates or instructors $(M=4.9, S D=0.9)$ than the native speaker American students. However, native speaker American adult students more often use effort regulation strategies, which indicates that they may have a high commitment to achieving their study goals $(M=5.8, S D=1)$.

Table 2. Non-Native Status Main Effect of Resource Management Strategies (RMS)

\begin{tabular}{lccccccc}
\hline \multirow{2}{*}{ RMS } & \multicolumn{2}{c}{$\begin{array}{c}\text { American Learners } \\
(n=179)\end{array}$} & $\begin{array}{c}\text { International ESL learners } \\
(n=54)\end{array}$ & $\boldsymbol{F}$ & $\boldsymbol{p}$ & \multirow{2}{*}{ Partial $\boldsymbol{\eta}^{\mathbf{2}}$} \\
\cline { 2 - 5 } & $\boldsymbol{M}$ & $\boldsymbol{S D}$ & $\boldsymbol{M}$ & $\boldsymbol{S D}$ & & & \\
\hline Effort & 5.8 & 1.0 & 5.3 & 1.1 & 9.2 & 0.003 & 0.04 \\
Peer & 3.4 & 1.6 & 4.5 & 1.5 & 16 & $<0.001$ & 0.07 \\
Help & 4 & 1.3 & 4.9 & 0.9 & 23 & $<0.001$ & 0.09 \\
\hline
\end{tabular}

Note. $N=236$, Significance level $=.05$

Additionally, gender and major had an interaction effect in two resource management strategies $(F=4.3, p=0.002)$ : TE $\left(F_{(1,233)}=9.5, p=0.003\right.$, partial $\left.\eta^{2}=0.04\right)$ and effort $\left(F_{(1,233)}=14, p<\right.$ 0.001 , partial $\left.\eta^{2}=0.06\right)$. In terms of TE, study major had significant influences among male students' resource management strategies with a moderate effect size $\left(F_{(1,99)}=6.6, p=0.012\right.$, partial $\left.\eta^{2}=0.06\right)$. Meanwhile, gender has a significant effect among non-STEM students' resource management strategies with a small effect size $\left(F_{(1,136)}=5.7, p=0.019\right.$, partial $\left.\eta^{2}=0.04\right)$. To be specific, male adult students in STEM fields spend more time in learning and often manage their learning environment compared to male adult students in non-STEM fields. However, among learners in non-STEM fields, female adult learners more often regulate their effort in studying compared to male adult learners. See Table 3 and 4.

Table 3. Gender and Major Interaction Effect for Resource Management Strategies (RMS)

\begin{tabular}{lccc}
\hline RMS & $\boldsymbol{F}$ & $\boldsymbol{p}$ & Partial $\boldsymbol{\eta}^{\mathbf{2}}$ \\
\hline Time and study environment (TE) & 9.5 & 0.002 & 0.04 \\
Effort & 14 & $<0.001$ & 0.06 \\
\hline
\end{tabular}


Table 4. Interaction Effect for Resource Management Strategies (RMS)

\begin{tabular}{|c|c|c|c|c|c|c|c|c|c|c|c|c|c|c|}
\hline \multirow{3}{*}{ RMS } & \multicolumn{4}{|c|}{ Male $(n=99)$} & \multicolumn{10}{|c|}{ Non-STEM $(n=137)$} \\
\hline & \multicolumn{2}{|c|}{ STEM } & \multicolumn{2}{|c|}{ Non-STEM } & \multirow[t]{2}{*}{$F$} & \multirow[t]{2}{*}{$p$} & \multirow[t]{2}{*}{ Partial $\eta^{2}$} & \multicolumn{2}{|c|}{ Male } & \multicolumn{2}{|c|}{ Female } & \multirow[t]{2}{*}{$\boldsymbol{F}$} & \multirow[t]{2}{*}{$p$} & \multirow[t]{2}{*}{ Partial $\eta^{2}$} \\
\hline & $M$ & $S D$ & $M$ & $S D$ & & & & $M$ & $S D$ & $M$ & $S D$ & & & \\
\hline & 55 & 0 & 51 & 08 & & & & & & 5 & 1.0 & & & \\
\hline Effort & 5.7 & 1.0 & 5.4 & 1.1 & 1.4 & 0.24 & 0.14 & 5.4 & 1.1 & 5.9 & 0.9 & 5.7 & 0.019 & 0.04 \\
\hline
\end{tabular}

Note. TE $=$ Time and study environment

Finally, non-native status, gender, and study majors have an interaction influence on TE $\left(F_{(1,233)}\right.$ $=5.6, p=0.019$, partial $\left.\eta^{2}=0.03\right)$ and effort $\left(F_{(1,233)}=9.1, p=0.003\right.$, partial $\left.\eta^{2}=0.04\right)$. See Table 5. Among the international ESL adult participants, study majors have a significant influence on their time and environment management strategies with a large effect size, respectively (male: $F_{(1}$, 34) $=5, p=0.033$, partial $\eta^{2}=0.13$; female: $F_{(1,20)}=11, p=0.004$, partial $\eta^{2}=0.38$ ). See Table 6 . To be specific, among international ESL female adult learners, study majors have a significant effect on their effort regulation with a large effect size $\left(F_{(1,20)}=11, p=0.004\right.$, partial $\left.\eta^{2}=0.37\right)$. In terms of male international ESL adult learners, those who study in STEM fields have better time management in studying and they often manage their learning environment better than those majoring in non-STEM fields. However, international ESL female adult students majoring in nonSTEM fields manage their study time better and they more often manage the learning environment better compared to STEM international ESL female adult learners. Similarly, non-STEM international ESL female adult students more often regulate their efforts in studying compared to international ESL female adult learners majoring in STEM fields.

Table 5. Non-Native Status, Gender and Major Interaction Effect for Resource Management Strategies (RMS)

\begin{tabular}{lccc}
\hline RMS & $\boldsymbol{F}$ & $\boldsymbol{p}$ & Partial $\boldsymbol{\eta}^{\mathbf{2}}$ \\
\hline Time and study environment (TE) & 5.6 & 0.019 & 0.02 \\
Effort & 9.1 & 0.003 & 0.04 \\
\hline
\end{tabular}

Table 6. Interaction Effect for Resource Management Strategies (RMS) Between International ESL adult learners

\begin{tabular}{|c|c|c|c|c|c|c|c|c|c|c|c|c|c|c|}
\hline \multirow{3}{*}{ RMS } & \multicolumn{4}{|c|}{$\begin{array}{l}\text { International ESL male } \\
\text { adult learners }(n=34)\end{array}$} & \multirow{3}{*}{$F$} & \multirow{3}{*}{$p$} & \multirow{3}{*}{$\begin{array}{l}\text { Partial } \\
\eta^{2}\end{array}$} & \multicolumn{4}{|c|}{$\begin{array}{c}\text { International ESL female } \\
\text { adult learners }(n=20)\end{array}$} & \multirow{3}{*}{$\boldsymbol{F}$} & \multirow{3}{*}{$p$} & \multirow{3}{*}{$\begin{array}{l}\text { Partial } \\
\eta^{2}\end{array}$} \\
\hline & \multicolumn{2}{|c|}{ STEM } & \multicolumn{2}{|c|}{ Non-STEM } & & & & & EM & Non & TEM & & & \\
\hline & $M$ & $S D$ & $M$ & $S D$ & & & & $M$ & $S D$ & $M$ & $S D$ & & & \\
\hline TE & 5.4 & 0.8 & 4.8 & 0.6 & 5 & 0.033 & 0.13 & 4.7 & 0.55 & 5.8 & 0.8 & 11 & 0.004 & 0.38 \\
\hline Effort & 5.7 & 1.0 & 5.4 & 1.1 & 1.4 & 0.239 & 0.14 & 4.8 & 1.30 & 6.3 & 0.8 & 11 & 0.004 & 0.37 \\
\hline
\end{tabular}

Note. $\mathrm{TE}=$ Time and study environment

\section{Discussions and Conclusions}

\section{Differences Between Learning Strategies Regarding Non-Native Status}

The results of this study indicate international ESL adult students use cognitive and metacognitive strategies, especially rehearsal and organization strategies more often than native speaker American adult students. This finding echoes previous studies where ESL learners have a high frequency in using self-regulated learning strategies (Poole, 2005; Seker, 2016). In terms of resource management strategies, native speaker American adult learners more often use effort regulations strategies. Meanwhile, international ESL adult students more often study with their classmates and they usually seek help from peers or instructors during learning. It is possible that language is an obstacle for these ESL learners to fully understand course materials by themselves, thus they often study and seek help from classmates and/or instructors. More research is needed to 
Lin: Self-regulated learning strategies of adult learners regarding non-native status, gender, and study majors

investigate this assumption. Although students of non-native status used different self-regulated learning strategies, these findings mirror previous studies where adult learners often apply a range of learning strategies and skills to learn knowledge (Mokhtar et al., 2017).

\section{Differences Between Learning Strategies Regarding Gender \& Study Majors}

Gender and study majors influence adult learners' self-regulated learning strategies. Female adult learners of non-STEM majors use effort regulation more often than their male counterparts, and they are more active strategy users in managing other resources during the learning process. These findings in some way echo previous conclusions where female learners are more actively applying self-regulated learning strategies than male students (Garrison \& Akyol, 2015), and they manage their learning environment more often than their male counterparts (Zimmerman \& Martinez-Pons, 1990). However, the difference using resource management strategies was only found between male and female adult learners in non-STEM fields, and the difference using cognitive and metacognitive strategies between male and female adult learners was not found in this study.

\section{Differences Between Learning Strategies Regarding Non-Native Status, Gender, \& Study Majors}

Chen and Lin (2018) found students in STEM-related domains showed a lower level of self-related regulation. Findings in the current study partially argued against and partly echoed this conclusion. This study discovered that both native speaker American and international ESL male adult students who studied in STEM majors had better time and environment management during the learning process compared to male adult learners who studied in non-STEM majors, respectively. Interestingly, international ESL female adult students from non-STEM majors had better study time and environment management and they more often used effort regulation strategies compared to international ESL female adult learners in STEM majors. Therefore, further study may consider investigating the level of course difficulty and students' understanding of the course materials based on different majors.

In conclusion, findings of this study suggest non-native status, gender, and study majors are associated with adult learner self-regulated learning strategies. International ESL adult learners had a higher frequency in using rehearsal and organization strategies. Additionally, they often study with peers and seek help from classmates and/or instructors, while these learners less often apply effort regulation during the learning process compared to native speaker American adult learners. Male and female students prefer a different use of self-regulated learning strategies, but only among adult learners who study in non-STEM majors. Meanwhile, male adult students from STEM majors are more active strategy users than male adult learners who study in non-STEM majors, while the situation was opposite among female adult learners majoring in non-STEMrelated programs.

\section{Theoretical Implications}

Altogether, this study contributes to the literature on self-regulated learning strategies of adult learners in terms of gender, non-native status, and study majors. First, this study indicated that adult learners apply a range of self-regulated learning strategies. They take responsibility for their learning, direction, and productivity to achieve study goals through better time and learning environment management.

Second, gender and study majors influenced adult learners' use of self-regulated learning strategies. Specifically, female non-STEM adult learners often used effort regulation strategies during the 
learning process compared to their male counterparts. In other words, non-STEM female adult learners had a higher level of self-regulation to control their effort and attention in order to complete their study goals compared to non-STEM male adult learners. In addition, male adult learners who study in STEM majors had better time and environment management during the learning process compared to non-STEM male adult learners.

Additionally, non-native status also affected the adoption of adult learners' self-regulated learning strategies. Compared with international adult learners, native speaker American adult learners often had a high commitment to achieve their study goals, while international ESL adult learners usually needed assistance from peers and/or instructors. Additionally, among the international ESL adult learners, female adult students from non-STEM majors had better time and environment management and they tried hard to achieve their goals.

\section{Practical Implications}

Overall, since adult learners are often willing to take responsibility for their learning, instructors should clearly note the course schedule such as the assignment due date, so these learners could make their study plans in advance. As adult learners usually have various roles such as full-time employers (Knowles, 1975), faculty members should also consider providing make-up assignments for adult students who may need an adjustment to balance the time of their work and study. In terms of managing their learning environment, universities may consider providing a study place which is organized, quiet, and relatively free of visual and auditory distractions specifically for adult learners, such as providing independent study rooms in the university's library.

In terms of gender and study majors, instructors may consider providing recognition to female adult learners in non-STEM areas in order to encourage them to continue using learning strategies to achieve their academic goals. Meanwhile, instructors should help male adult learners from nonSTEM disciplines to establish their study goals to encourage them to be more effort regulated and work toward their goals. Instructors may also encourage male adult learners from STEM-related programs to continue to manage their study time and to complete their study goals, while faculty members who teach male adult learners in non-STEM majors may consider consulting with these learners to make timetables or management charts in order to achieve their academic commitments.

In terms of student status, instructors should provide recognition to native American adult learners to keep working on their academic goals. In terms of international ESL adult learners, faculty members could consider assigning them to another peer who is willing to help them with school work. Universities may consider providing similar service such as a study partner program to help these learners learn. Regular meetings with instructors or advisors should also be arranged for these adult learners to discuss their learning progress and learning difficulties during their learning process, thus timely assistance could be provided. Additionally, instructors should encourage international ESL adult learners in non-STEM majors to continue managing their study time and using effort regulation strategies to complete their study goals. In terms of international ESL female adult learners in STEM-related disciplines, faculty members may consider discussing with these learners setting or clarifying their study goals and establishing timetables or management charts in order to help them work toward their academic goals. 
Lin: Self-regulated learning strategies of adult learners regarding non-native status, gender, and study majors

\section{Limitations and Future Research}

Several limitations existed in this study. First, this study relied on a self-reported questionnaire, future research should include qualitative studies such as focus group or interviews to further explore self-regulated learning strategies of adult learners, which may serve as evidences or arguments to the findings of this study. Second, this study excluded adult learners who were younger than 25 years old and did not continue to enroll in a formal education system. As a result, further investigation is needed to explore this student population. Additionally, information was gathered from participants in a large southeastern research university, data might not represent all adult learners in the US. Meanwhile, this study only involved graduate students, adult learners in undergraduate programs may use self-regulated learning strategies differently. As a consequence, more students from different programs and institutions should be recruited. Further research should also investigate factors which lead to a high frequency use of peer learning and help seeking strategies among international ESL adult learners. Finally, future study could also explore the differences of using self-regulated learning strategies between adult and traditional learners regarding their non-native status, gender, and study majors in order to better understand and serve diverse learners during their learning process.

\section{References}

Baily, C. A. (1996). Unobtrusive computerized observation of compensation strategies for writing to determine the effectiveness of strategy instruction. In R. L. Oxford (Ed.) Language learning strategies around the world: Cross-cultural perspectives (pp. 141-150), Honolulu, HI: University of Hawaii, Second Language Teaching \& Curriculum Center.

Bandura, A. (1997). Self-efficacy: The exercise of control, New York, NY: W. H. Freeman.

Bidjerano, T. (2005, October). Gender differences in self-regulated learning. Paper presented at the Annual Meeting of the Northeastern Educational Research Association, Kerhonkson, NY, USA.

Broadbent, J., \& Poon, W. L. (2015). Self-regulated learning strategies \& academic achievement in online higher education learning environments: A systematic review. The Internet and Higher Education, 27, 1-13.

Bye, D., Pushkar, D., \& Conway, M. (2007). Motivation, interest, and positive affect in traditional and nontraditional undergraduate students. Adult Education Quarterly, 57(2), 141-158.

Cantwell, B. (2015). Are international students cash cows? Examining the relationship between new international undergraduate enrollments and institutional revenue at public colleges and universities in the US. Journal of International Students, 5(4), 512-525.

Chen, Y. H., \& Lin, Y. J. (2018). Validation of the short self-regulation questionnaire for Taiwanese college students (TSSRQ). Frontiers in Psychology, 9, 259. doi: 10.3389/fpsyg.2018.00259

Cortina, J. M. (1993). What is coefficient alpha? An examination of theory and applications. Journal of Applied Psychology, 78(1), 98-104.

Flavell, J. H. (1978). Metacognitive development. In J. M. Scandura \& C. J. Brainerd (Eds.), Structural process models of complex human behavior (pp. 213-245). Alphen a.d. Rijn, Netherlands: Slijthoff \& Noordhoff.

Garrison, D. R., \& Akyol, Z. (2015). Toward the development of a metacognition construct for communities of inquiry. The Internet and Higher Education, 24, 66-71.

Goh, C., \& Foong, K. P. (1997). Chinese ESL students' learning strategies: A look at frequency, proficiency, and gender. Hong Kong Journal of Applied Linguistics, 2(1), 39-53.

Han, S., Capraro, R., \& Capraro, M. M. (2015). How science, technology, engineering, and mathematics (STEM) project-based learning (PBL) affects high, middle, and low achievers differently: The impact of student factors on achievement. International Journal of Science and Mathematics Education, 13(5), 1089-1113.

Hegarty, N. (2011). Adult learners as graduate students: Underlying motivation in completing graduate programs. The Journal of Continuing Higher Education, 59(3), 146-151.

Hirai, R., Frazier, P., \& Syed, M. (2015). Psychological and sociocultural adjustment of first-year international students: Trajectories and predictors. Journal of Counseling Psychology, 62(3), 438.

Hong-Nam, K., \& Leavell, A. G. (2006). Language learning strategy use of ESL students in an intensive English learning context. System, 34(3), 399-415. doi: 10.1016/j.system.2006.02.002

Hosenfeld, C. (1976). Learning about learning: Discovering our student's strategies. Foreign Language Annals, 9, 117-129. 
Iwai, Y. (2011). The effects of metacognitive reading strategies: Pedagogical implications for EFL/ESL teachers. The Reading Matrix, 11(2), 150-159.

Kasworm, C. E., Polson, C. J., \& Fishback, S. J. (2002). Responding to adult learners in higher education. Malabar, FL: Krieger.

Kellenberg, F., Schmidt, J., \& Werner, C. (2017). The adult learner: Self-determined, self-regulated, and reflective. Signum Temporis, 9(1), 23-29.

Kim, D. H., Wang, C., Ahn, H. S., \& Bong, M. (2015). English language learners' self-efficacy profiles and relationship with self-regulated learning strategies. Learning and Individual Differences, 38, 136-142.

Kitsantas, A., Steen, S., \& Huie, F. (2017). The role of self-regulated strategies and goal orientation in predicting achievement of elementary school children. International Electronic Journal of Elementary Education, $2(1), 65-81$.

Knowles, M. S. (1975). Self-directed learning. New York, NY: Association Press.

Knowles, M. S. (1980). The modern practice of adult education: From pedagogy to andragogy (Rev. ed.). Chicago, IL: Association/Follett.

Lin, X., \& Wang, C. H. (2015). Factors that affect returning to graduate school for international and American adult learners. Institute for Learning Styles Journal, 1, 40-53.

Littlejohn, A., Hood, N., Milligan, C., \& Mustain, P. (2016). Learning in MOOCs: Motivations and self-regulated learning in MOOCs. The Internet and Higher Education, 29, 40-48.

Markle, G. (2015). Factors influencing persistence among nontraditional university students. Adult Education Quarterly, 65(3), 267-285.

Mega, C., Ronconi, L., \& De Beni, R. (2014). What makes a good student? How emotions, self-regulated learning, and motivation contribute to academic achievement. Journal of Educational Psychology, 106(1), 121-131.

Mertler, C. A., \& Vannatta, R. A. (2002). Advanced and multivariate statistical methods. Los Angeles, CA: Pyrczak.

Mesidor, J. K., \& Sly, K. F. (2016). Factors that contribute to the adjustment of international students. Journal of International Students, 6(1), 262-282.

Miller, D. A. (2015). Learning how students learn: An exploration of self-regulation strategies in a two-year college general chemistry class. Journal of College Science Teaching, 44(3), 11-16. doi: 10.2505/4/jcst150440311

Mokhtar, A. A., Rawian, R. M., Yahaya, M. F., Abdullah, A., \& Mohamed, A. R. (2017). Vocabulary learning strategies of adult ESL learners. The English Teacher, 12, 133-145.

Mousoulides, N., \& Philippou, G. (2005, July). Students' motivational beliefs, self-regulation strategies and mathematics achievement. Paper presented at the 29th Conference of the International Group for the Psychology of Mathematics Education, Melbourne, Australia.

Opendoors. (2018). International students infographics. Open Doors. Retrieved from http://www.iie.org/Researchand-Publications/Open-Doors/Data/International-Students/Infographic

Ozturk, M. (2015). Vocabulary growth of the advanced EFL learner. The Language Learning Journal, 43(1), 94109.

Pintrich, P. R. (1999). The role of motivation in promoting and sustaining self-regulated learning. International Journal of Educational Research, 31(6), 459-470. doi: 10.1016/S0883-0355(99)00015-4

Pintrich, P. R., \& Garcia. T. (1991). Student goal orientation and self-regulation in the college classroom. In M. Maehr \& P. R. Pintrich (Eds.) Advances in motivation and achievement: Goals and self-regulatory processes (pp. 371-402). Greenwich, CT: JAI Press.

Pintrich, P. R., Smith, D. A. F., Garcia, T., \& McKeachie, W. J. (1993). Reliability and predictive validity of the Motivated Strategies for Learning Questionnaire (MSLQ). Educational and Psychological Measurement, $53,801-813$.

Pokay, P., \& Blumenfeld, P. C. (1990). Predicting achievement early and late in the semester: The role of motivation and use of learning strategies. Journal of Educational Psychology, 82, 41-50.

Poole, A. (2005). Gender differences in reading strategy use among ESL college students. Journal of College Reading and Learning, 36(1), 7-20.

Rabourn, K. E., Shoup, R., \& BrckaLorenz, A. (2015, May). Barriers in returning to learning engagement and support of adult learners. Paper presented at the Annual Forum of the Association for Institutional Research, Denver, CO, USA.

Schunk, D., \& Zimmerman, B. (1994). Self-regulation of learning and performance: Issues and educational applications. Hillsdale, NJ: Erlbaum.

Seker, M. (2016). The use of self-regulation strategies by foreign language learners and its role in language achievement. Language Teaching Research, 20(5), 600-618.

Shmais, W. A. (2003). Language learning strategy use in Palestine. TESL-EJ, 7(2), 1-13.

Spitzer, T. M. (2000). Predictors of college success: A comparison of traditional and nontraditional age students. NASPA Journal, 38(1), 82-98. 
Szoke, E., \& Sheorey, R. (2002). A comparative study of the learning strategies of Hungarian and Russian college students. novELTy, 9(3), 23-36.

Whalen, D. F., \& Shelley, M. C. (2010). Academic success for STEM and non-STEM majors. Journal of STEM Education: Innovations and research, 11(1), 45-60.

Wolters, C. A. (1998). Self-regulated learning and college students' regulation of motivation. Journal of Educational Psychology, 90, 224-235.

Wolters, C. A., \& Hussain, M. (2015). Investigating grit and its relations with college students' self-regulated learning and academic achievement. Metacognition and Learning, 10(3), 293-311.

Yakunina, E. S., Weigold, I. K., \& Weigold, A. (2013). Personal growth initiative: Relations with acculturative stress and international student adjustment. International Perspectives in Psychology: Research, Practice, Consultation, 2(1), 62-71.

Yang, T. C., Hwang, G. J., \& Yang, S. J. H. (2013). Development of an adaptive learning system with multiple perspectives based on students' learning styles and cognitive styles. Journal of Educational Technology \& Society, 16(4), 185-200.

Yukselturk, E., \& Bulut, S. (2007). Predictors for student success in an online course. Journal of Educational Technology \& Society, 10(2), 71-83

Zimmerman, B. J. (1989). Models of self-regulated learning and academic achievement. In B. Zimmerman \& D. Schunk (Eds.) Self-regulated learning and academic achievement: Theory, research, and practice (pp. 125). New York: Springer-Verlag.

Zimmerman, B. J. (1990). Self-regulated learning and academic achievement: An overview. Educational Psychologist, 25, 3-17.

Zimmerman, B. J. (2000). Attaining self-regulation: A social cognitive perspective. In M. Boekaerts, P. R. Pintrich, \& M. Zeidner (Eds.) Handbook of self-regulation (pp. 13-39). San Diego, CA: Academic.

Zimmerman, B. J. (2008). Investigating self-regulation and motivation: Historical background, methodological developments, and future prospects. American Educational Research Journal, 45(1), 166-183.

Zimmerman, B. J., \& Martinez-Pons, M. (1986). Development of a structured interview for assessing student use of self-regulated learning strategies. American Educational Research Journal, 23, 614-628.

Zimmerman, B. J., \& Martinez-Pons, M. (1988). Construct validation of a strategy model of student self-regulated learning. Journal of Educational Psychology, 80, 284-290. doi: 10.1037/0022-0663.80.3.284

Zimmerman, B. J., \& Martinez-Pons, M. (1990). Student differences in self-regulated learning: Relating grade, sex, and giftedness to self-efficacy and strategy use. Journal of Educational Psychology, 82(1), 51-59.

Zimmerman, B. J., \& Schunk, D. H. (2008). Motivation: An essential dimension of self-regulated learning. In D. H. Schunk \& B. J. Zimmerman (Eds.) Motivation and self-regulated learning: Theory, research, and applications (pp. 1-30). Mahwah, NJ: Erlbaum. 